\title{
The regulatory experience of Italy and the United States with dedicated incentives for strategic electricity transmission investment
}

\author{
Nico Keyaerts ${ }^{\mathrm{a}, \mathrm{b}}$ and Leonardo Meeus $\mathrm{s}^{\mathrm{a}, \mathrm{b}}$ \\ ${ }^{\text {a }}$ Florence School of Regulation, Robert Schuman Centre for Advanced Studies, European University Institute, \\ Via Boccaccio 121, I-50133 Florence, Italy. \\ ${ }^{\mathrm{b}}$ Vlerick Business School, Vlerick Energy Centre, Bolwerklaan 21, B-1210 Brussels, Belgium. \\ nico.keyaerts@eui.eu, +39 0554685 878, Florence School of Regulation, Robert Schuman Centre for Advanced \\ Studies, European University Institute, Via Boccaccio 121, I-50133 Florence, Italy.
}

\begin{abstract}
There is a trend in regulatory practice towards providing dedicated incentives for strategic investments. Italy and the United States have the longest experience with authorizing returns and riskmitigating incentives that deviate from standard regulatory treatment for policy purposes. In these countries, the regulatory incentives are based on a case-by-case assessment of capital projects. We find that the Italian scheme is simpler, which reduces administrative costs. The U.S. scheme is more advanced in the case-by-case assessment. Even though dedicated incentives may be controversial, our analysis of both experiences shows that, notwithstanding significant learning costs, both schemes have facilitated substantial financial investment in strategically important infrastructure.
\end{abstract}

\section{Keywords}

Electricity transmission; Transmission grid; Interconnection; Incentive regulation

\section{Introduction}

The regulatory frameworks that apply to electricity transmission investments predominantly authorize comparable returns to all electricity infrastructure projects, irrespective of their costs and benefits, and irrespective of their unique risk profiles. Historically, and after vertical separation of transmission, there were sound economic reasons to uniformly remunerate all past and new investment in regulated asset base (RAB) based on the averaged risk profile of transmission firms (in the US) or transmission system operators (TSO) in Europe. Remunerating investment via the RAB constitutes a commitment by the regulatory authority so that the investor can recover the costs of past and new investment over the whole range of the risk spectrum and transferring much of the investment risk to electricity customers (Helm, 2009). Based on its historic success, it is easy to believe that this approach can be adapted to implement premium returns on investments that are deemed riskier than average.

In the years following the liberalization, raising the efficiency of the TSOs for the benefit of electricity customers became the primary objective in most European countries. This objective lead countries to move away from cost-of-service regulation that is more investment friendly by passing on all costs and thus most risk to customers, towards the application of incentive-based regulation with an ex ante cap on allowed revenues and efficiency targets that put more risk on investors (Brunekreeft and Meyer, 2011; Jamasb and Pollitt, 2001; Microeconomix, 2008). The increased risk for the TSO will not compromise regular investment as long as the risk profile of the investment does not deviate from the average risk profile of the firm, which determines the revenue cap.

Today, however, many TSOs face again the need to invest more in strategically important projects that support the realization of national and EU energy and climate objectives. Considering that electricity markets and grids often cross geopolitical borders, strategic transmission investment is increasingly 
addressed at the regional level, as seen by the many interstate projects in the U.S. ${ }^{1}$ or by the projects of common interest in Europe ${ }^{2}$.

Where there are significant transmission investment needs, regulatory authorities face an important question: how can the regulatory framework balance the objectives of incentivizing investment, on the one hand, and incentivizing efficiency improvements, on the other? Glachant et al. (2013) argue that in the tradeoff between the investment risk and the remuneration of the transmission firm, the national regulatory framework should ensure that the remuneration is sufficient for all investment, including the investment that is subject to greater cost uncertainty. This approach is fine to the extent that the necessary investment is comparable to regular investment. However, it could be less costly to offer dedicated incentives only to the strategically important investment, on a case-by-case basis, whereas regular investment remains subject to standard regulatory treatment. These dedicated incentives comprise a customization of one or more of the main regulatory parameters, which are the length of the regulatory period, the return on equity, the specified efficiency targets, and the scope of the revenue cap.

This issue has initiated a debate among practitioners in Europe in terms of regulatory policy for strategically important investment, especially if the investment has impacts across several countries. It could be argued that strategic projects should be dealt with in the same way as regular national investment because the standard regulatory treatment sufficiently addresses the risks of strategically important projects, or it could be argued that these projects justify dedicated regulatory treatment. The European Agency for Collaboration of Energy Regulators has documented all incentives for transmission investment that are currently applied in EU Member States (ACER, 2014), finding that most countries already foresee several risk mitigating measures. The debate on the two approaches, however, is very much open,

More and more countries are experimenting with dedicated regulatory incentives to speed up strategic transmission investment. Investment incentives are decided case by case, first deciding on the eligibility of a project for dedicated incentives and next deciding on an appropriate incentive package. Case-by-case incentives, however, are very controversial as they are often associated with merchant investment and their adoption could make it easier for third-party investors to contest the regulated monopoly for some projects. Nevertheless, dedicated incentives have been rolled out in several countries. In the UK, for instance, several dedicated incentives already exist for the connection of offshore wind farms to the mainland (Meeus, 2014) as well as one for interconnectors to speed up EU market integration (Meeus and Keyaerts, 2014). France is also in the process of setting up dedicated incentives for interconnectors for the same reason. In Germany, large domestic and cross-border gridexpansion investments that support the German Energiewende are accelerated with dedicated incentives for what they consider strategically important investment.

However, the longest and richest experiences with dedicated regulatory incentives for strategic transmission investments are, in Italy and the U.S. In the U.S., dedicated incentives have driven an estimated $\$ 13$ billion of commissioned investments in the period 2006-2012 (Lum, 2012), with transmission investment steadily increasing after 2005, when the dedicated incentives scheme became effective (EEI, 2013, 2016). In Italy, nearly thirty large infrastructure projects, representing billions of euro in investment, have been funded through the dedicated incentive scheme (AEEGSI, 2014a, 2014b 2016; Terna, 2006, 2010, 2014). The contribution of this paper is to analyze the experiences of these two countries in detail. We show that even though there are significant learning costs in their implementation, dedicated incentives have succeeded in speeding up the implementation of strategically important infrastructure projects. ${ }^{3}$

\footnotetext{
${ }^{1}$ See, for instance, the respective regional transmission plans in PJM, MISO, CAISO, etc.

${ }^{2}$ See the 2013 list of projects in Commission delegated Regulation (EU) No 1391/2013 of 14.10.2013 amending Regulation (EU) No 347/2013 of the European Parliament and of the Council on guidelines for trans-European energy infrastructure as regards the Union list of projects of common interest. (EC, 2013a, 2013b)

${ }^{3}$ The level of success is however hard to objectively assess because there is no counterfactual case.
} 
The paper is organized as follows. Section 2 introduces the main logic of dedicated regulatory incentives through the Italian and U.S. implementation experiences. In this section we also compare the two approaches to provide dedicated incentives, finding that, even though the conceptual designs are significantly different, the available evidence suggests that both succeeded in speeding up investment. Section 3 describes how both schemes have evolved over time into more sophisticated and complex schemes, illustrating the significant learning costs involved. The paper concludes with the lessons learned for policy makers and regulatory authorities.

\section{Dedicated regulatory incentives: comparison of Italy and the US}

Dedicated incentives typically follow a two-step logic: (1) limiting access to the dedicated incentives to strategically important projects, and (2) offering dedicated incentives to facilitate the implementation of those important investments. The two-step logic is illustrated below for the Italian and for U.S. regulatory frameworks, respectively.

\subsection{Introduction to the Italian experience}

The Italian policy makers, led by the Italian national regulatory authority, decided to prioritize important expansions of the transmission grid that were deemed necessary to promote competition and improve market integration in the aftermath of a countrywide blackout in 2003 (AEEG, 2003, 2005). We examine the Italian experience during the fourth regulatory period, which covers 2012-2015 (AEEG, 2011a, 2011b, 2013a; AEEGSI 2014b). During this period, twenty-five projects received dedicated incentives for important transmission investments (AEEG, 2013a; AEEGSI 2014b). Some of these projects are under construction or near completion, whereas other projects are at the stage of obtaining permits. In what follows, we first discuss the access to this scheme, and then the type of dedicated incentives that can be granted under the scheme.

\subsubsection{Access to dedicated incentives in Italy}

As illustrated in the upper part of Figure 1, the developer submits the proposed project to the Italian regulatory authority. The authority then assesses whether the project is either an interconnection that connects Italy to neighboring countries, or a domestic transmission line that will reduce internal congestion. Both may constitute strategically important investments, given underlying policy objectives are increasing market integration and reliability.

Following a positive assessment ${ }^{4}$ of the investment, the project is granted access to the three types of dedicated incentives that are discussed below. In case of a negative assessment, the project receives the standard regulatory treatment for transmission investment. Any approved project automatically exits the dedicated incentive scheme after a predefined period, which is currently after twelve years of operational service of the transmission project, which is a significant extension of the standard fouryear length of the regulatory period. It subsequently receives the standard treatment for its remaining regulatory lifetime. As the scheme has been initiated in the second regulatory period 2004-2007, the earliest such exit, after twelve years, will occur in 2016.

To sum up, access to the dedicated incentives in Italy is limited in time, and also limited by predefining eligible project categories, which is relatively simple to administer. The Italian regulatory authority for energy $\mathrm{AEEG}^{5}$ did not create a specialized department to administer this scheme, and is simply relying on the existing staff ${ }^{6}$.

\footnotetext{
${ }^{4}$ Little information could be found on this internal procedure to assess projects.

${ }^{5}$ As of 2014, AEEG changed its name into AEEGSI to reflect that it also regulates hydro systems.

${ }^{6}$ Staff numbers of AEEG amounted to approximately 180 at the end of 2013 (http://www.autorita.energia.it).
} 


\subsubsection{Type of dedicated incentives in Italy}

In the Italian scheme, there are three types of dedicated incentives (Figure 1): (1) a premium return on investment for completed projects; (2) a premium for work in progress; and (3) a penalty for projects exceeding their planned commissioning date. The latter two incentives are voluntary. Developers can ask for the additional work in progress incentives, but only if they then also accept being exposed to the penalties associated with delays. All three incentives customize the return on investment, whereas the latter two incentives also customize the scope of the revenue cap by allowing the inclusion of work in progress.

How they are administered is as follows. First, upon completion of a project, a two-percentage point increase over the standard return on investment is automatically awarded for twelve years. Second, work in progress qualifies for a two-percent premium conditional on making sufficient progress with authorization or construction work. Progress is measured through an assessment of annual milestones. These milestones are expressed in a monetary value and are set for each project by the regulatory authority in agreement with the project developer upon entry into the scheme. Each year, the regulatory authority assesses for the aggregated work in progress whether a project developer has met at least seventy percent of the accumulated value of the company's milestones of the previous year. If the threshold is met, the project developer gets a two percent premium for all work in progress by 31 December of the previous year. While there is a case-by-case element in setting the milestones, the actual assessment looks only at the aggregated level of all projects of a project developer: about $74 \%$ of ongoing investments met their milestones in the first half of 2013 (AEEG, 2013b); more than $90 \%$ of ongoing investments met their milestones in the second half of 2013 (AEEGSI, 2014a). The upward trend continued for 2014 when more than $97 \%$ of the ongoing investments met their milestones, but performance dropped ${ }^{7}$ somewhat to about $75 \%$ for 2015 , which was still above the threshold. Third, if the actual commissioning date exceeds the planned date by more than twelve months, the project developer must pay a lump sum penalty to the regulatory authority in the amount of two percent calculated on $110 \%$ of the invested capital and pro rata of the months that the project is late.

In other words, the dedicated incentives in Italy are, to a large extent, the same for all projects that are granted access to the scheme with the exception of projects that do not meet their milestones, and/or commissioning dates. There is an element of case-by-case assessment of projects, but it is limited to the establishment of milestones and the monitoring of progress. Finally, while the incentives are mostly positive, there are also penalties for delays.

\footnotetext{
${ }^{7}$ The completion of the $380 \mathrm{kV}$ line between Sorgente and Rizziconi did not complete works on time and accounted for $17.5 \%$ of the ongoing investments; the project has been inaugurated in May 2016.
} 
Figure 1: Flowchart of the dedicated regulatory scheme for strategic electricity transmission investment applicable in Italy for the fourth regulatory period (2012-2015)

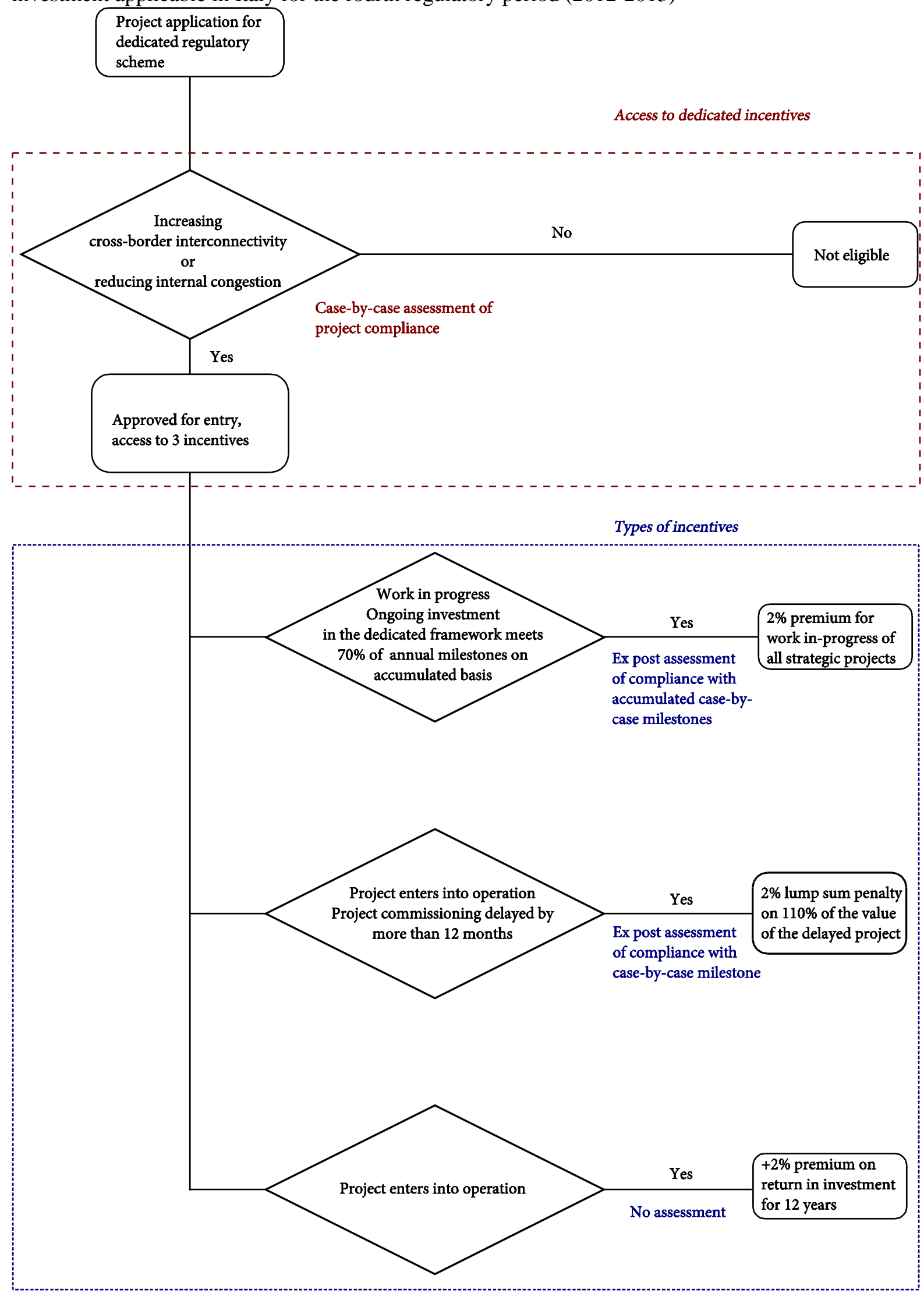




\subsection{Introduction to the U.S. experience}

In 2003, the U.S. also faced a large blackout. A task force report following the incident identified the failing transmission grid as an aggravating factor (U.S.-Canada Power System Outage Task Force, 2004). Furthermore, the U.S. had been observing decades of declining transmission investment (Benjamin, 2007; Hirst and Kirby, 2001; Hirst, 2004). This led to the conclusion by policy makers that additional incentives were necessary for investment in regional reliability projects. Subsequently, in the Energy Policy Act of 2005, the Federal Energy Regulatory Commission (FERC), which regulates transmission based on federal authority for interstate ${ }^{8}$ commerce, was mandated to set up a new scheme to promote strategic transmission investment (FERC, 2006b, 2006c, 2012). By 2012, around 85 applications for entry had been filed, representing billions of U.S. dollar in investment and covering more than a hundred infrastructure projects (FERC, 2012). In what follows, we discuss access to this scheme and the types of dedicated incentives that can be granted under the scheme.

\subsubsection{Access to dedicated incentives in the US}

As illustrated in the upper part of Figure 2, the strategic importance of the project is first established through case-by-case assessment in the US. There are three ways for a project developer to demonstrate the importance of a proposed project. The first is for the project to be included in a regional transmission expansion plan ${ }^{9}$ (RTEP) that performs an assessment of the reliability and/or congestion impact. In that case, the regulatory authority presumes that the project is indeed important. If a project is not included in a RTEP, the project developer can submit alternative evidence such as private technical studies to demonstrate the impact on the regional transmission grid. The regulatory authority evaluates this evidence and decides whether the project is indeed important or not. The third option available to the project developer is to apply for access that is conditional to a pending inclusion of the project into the RTEP process. The second step in the entry process is the so-called "nexus test". Project developers have to demonstrate the extraordinary risk of their proposed projects. The extraordinary nature of the project can come from the financial size of the project compared to the existing assets of the project developer, the innovativeness of the technology, or other practical challenges. The regulatory authority has provided further guidance on how to demonstrate extraordinary risk in its case-by-case rulings (see section 3 ).

Following FERC's positive assessment of the provided evidence, a project can be granted access to as many as ten dedicated incentives: (1) a premium return on investment; (2) 100\% cost recovery of prudently incurred construction work in progress; (3) $100 \%$ cost recovery of prudently incurred preconstruction costs; (4) $100 \%$ cost recovery of prudently incurred costs of a stranded project; (5) the use of hypothetical capital structures; (6) accumulated deferred income taxes for transmission companies; (7) adjustments to book value for sales)purchases; (8) accelerated depreciation; (9) deferred cost recovery for utilities with retail rate freezes; and (10) a higher rate of return for utilities that join and/or continue to be members of transmission organizations, such as RTOs and ISOs. ${ }^{10}$

In case of a negative assessment, the project receives the standard treatment for transmission investment, i.e., investors get the standard return on investment that has been set for the company. Any approved project automatically exits the dedicated incentive scheme after a predefined period, which is currently at the end of the regulatory lifetime of the transmission project. FERC will consider accelerated depreciation as short as fifteen years ${ }^{11}$ as one of the incentives that can be accessed. As the dedicated incentive scheme initiated in 2006, the earliest any strategic investment in the scheme would reach the end of its regulatory lifetime is 2021 .

\footnotetext{
${ }^{8}$ Intrastate transmission investment that has no regional impact is under the jurisdiction of state regulators. Interstate investment that is not strategically important receives standard ratemaking treatment by FERC.

${ }^{9}$ A regional transmission expansion plan can be organized by an Independent System Operator (ISO) or a Regional Transmission Operator, depending on the local organization of the electricity system.

${ }_{10}$ An overview is provided on: https://www.ferc.gov/industries/electric/indus-act/trans-invest.asp

${ }^{11}$ FERC would even consider depreciation periods below 15 years case-by-case, if well motivated.
} 
To sum up, access to the dedicated incentives in the U.S. is limited to the regulatory lifetime of the asset, and also controlled by a two-step case-by-case assessment of projects. This can be relatively costly to administer for the regulatory authority. However, the burden of proof is on the project developers, and the decision is taken at the federal instead of the state level in the US, which reduces administrative costs. Still, to implement this scheme, the FERC expanded its staff with a few dozen full-time equivalent employees between 2006 and $2009^{12}$.

\subsubsection{Type of dedicated incentives in the US}

Of the ten dedicated incentives in the U.S. scheme ${ }^{13}$; the four that are most used are discussed here (Figure 2): (1) a premium return on investment; (2) a $100 \%$ cost recovery of work in progress during construction; (3) a recovery of pre-construction costs; and (4) 100\% cost recovery in the case of a stranded project. The first customizes the remuneration of capital, whereas the next two dedicated incentives customize the scope of the revenue base. The fourth type of dedicated incentives offers a cost pass through in case of investment that subsequently turns out to be inefficient.

How they are administered is as follows. For each incentive requested, the project developer must demonstrate with factual evidence that the particular incentive is necessary to proceed with the project. A project developer can, for instance, request a premium return on investment to cover the challenges of applying an innovative technology to the project. Or a developer can provide evidence of cash-flow or financing challenges that can be mitigated with the full recovery of pre-construction costs or the inclusion of construction work in progress in the ratebase. If a project is still in the early stages of development and is, for example, dealing with several authorities, the developer could also request an incentive that allows full recovery of costs in case of a stranded project, where abandonment is beyond its control.

The developer also has to demonstrate that the total package of incentives matches the risk of the project. There are several rulings by FERC on the regulatory treatment of a project in which the level of the requested premium was decreased because other incentives that reduce the project risk had also been granted. In other words, dedicated incentives for transmission in the U.S. are strongly dependent on an assessment of project risk and the evidence presented by the project developer. The U.S. scheme therefore has three elements of case-by-case assessment: (1) strategic importance, (2) project risk, and (3) the appropriateness of the proposed package of dedicated incentives relative to project risk.

\footnotetext{
${ }^{12}$ According to its annual budget requests (FERC, 2006a, 2007a, 2008a), FERC requested +25 full time equivalents for fiscal year $2007,+75$ for 2008 and +65 for 2009 dedicated - at least in part - to the implementation of the competences laid out in the Energy Policy Act of 2005.

${ }^{13}$ Snarr (2007) and Daileader (2007) are two authors that have previously discussed these incentives.
} 
Figure 2: Flowchart of the dedicated regulatory scheme for strategic electricity transmission investment applicable in the U.S. since 2006

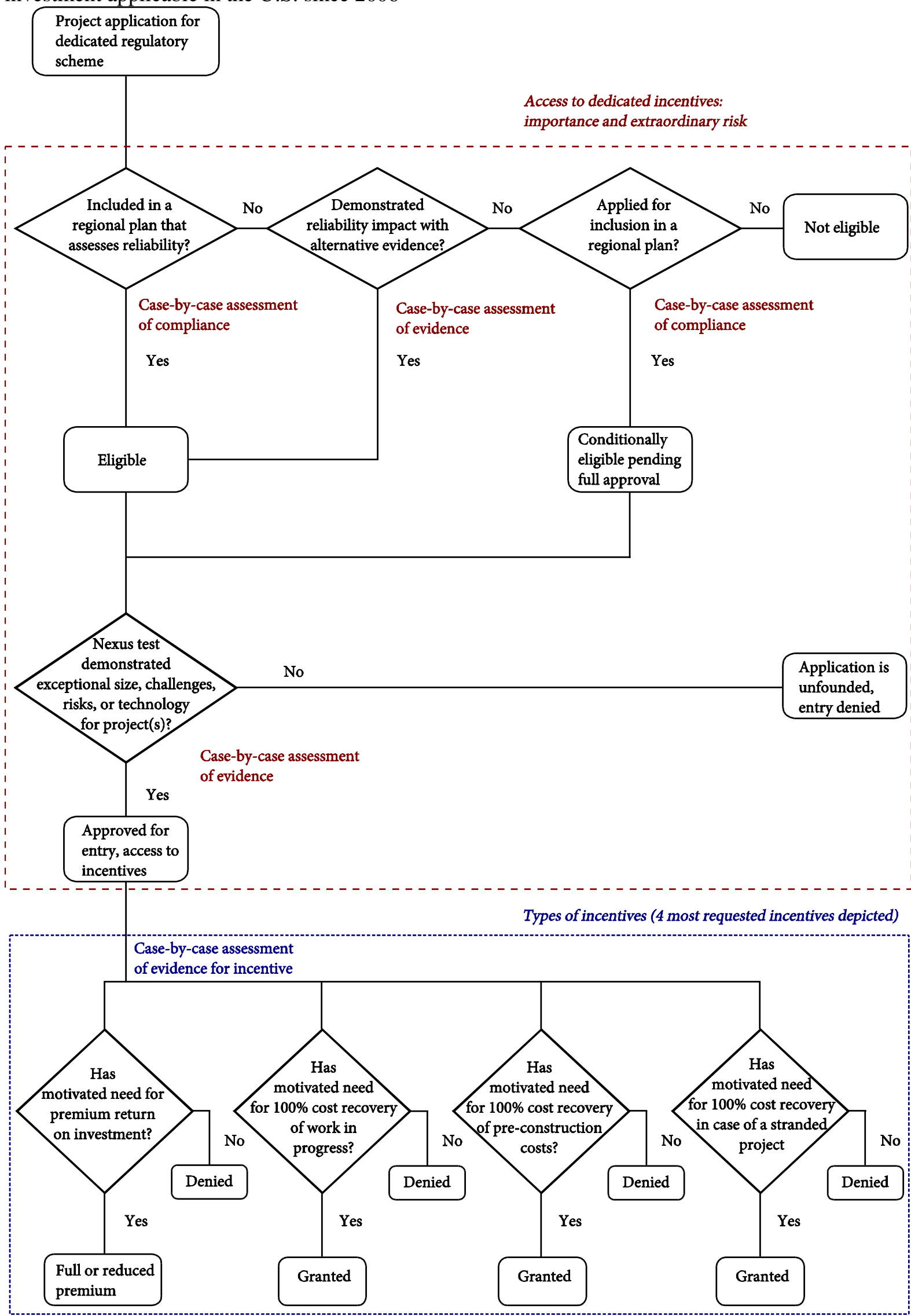




\subsection{Comparison of the Italian and the U.S. experience}

\section{Commonalities of the experiences}

The contexts in which the Italian and U.S. schemes to provide dedicated regulatory incentives for strategic electricity transmission investments have been developed are very similar. In both cases, a blackout triggered the change in regulatory practice, based on a perception of lacking transmission investment under standard regulatory treatment. The two approaches have in common that they control the costs of the scheme by limiting access to the dedicated incentives. They also have in common that the incentives are not necessarily the same for all projects and that the incentives are a package of measures focused on either reducing the risk to project developers or increasing their return on investment.

\section{Differences between the experiences}

There are also clear differences between the Italian and the U.S. experiences. The U.S. scheme is more advanced in the case-by-case assessment of the requested incentives. As discussed above, there are three assessment steps encompassing strategic importance, project risk, and appropriateness of dedicated incentives. The incentive package in the U.S. is more advanced. FERC considers a wider scope of the risk and return on investments and can be adapted to each project. In comparison, the Italian scheme is simpler, using the type of project as a proxy for its strategic importance and granting a premium return on investment, regardless of project-specific risks. Because of its simplicity, the Italian scheme is less costly to administer. The higher costs of the U.S. scheme, however, are borne at federal level allowing some economies of scale to be captured. A comparable scheme for Europe might be to have the Agency for the Cooperation of Energy Regulators (ACER) perform case-by-case assessments of international projects of common interest.

\section{Outcomes following the dedicated incentives}

Despite the differences, both the Italian and the U.S. experience suggest that dedicated incentives are successful in committing investment to strategically important projects.

In Italy, up to 2016, nearly thirty strategically important projects had been or are being implemented, at a value of several billion euro. Among the projects covered by the dedicated regulatory scheme are cross-border interconnections to France and to Montenegro, ten major $380 \mathrm{kV}$ transmission lines in the north and the south regions of Italy, several reinforced connections to the Italian isles, and the refurbishment and streamlining of the transmission networks in metropolitan areas such as Milan, Torino, Napoli and Palermo (AEEGSI, 2014a, 2016; Terna, 2012).

In the United States, between 2006 and 2012, several dozen projects valued at more than $\$ 13$ billion were approved and commissioned under FERC's dedicated incentive scheme (Lum, 2012). ${ }^{14}$ Furthermore, it was estimated that an additional $\$ 23$ billion of already approved ${ }^{15}$ investment would be commissioned by 2016. Moreover, a notable increase in the amount of capital invested into the transmission system coincides with the implementation of the dedicated regulatory scheme as illustrated in Figure 4. Notable examples are the Energy Gateway project that is adding over 2000 miles of transmission lines in the Pacific region (EEI, 2016; Pacificorp, 2016); thirty-six projects by Virginia Electric Power to revamp the transmission grid in the Virginia-Maryland area (Dominion,

\footnotetext{
${ }^{14}$ For an overview of the FERC decisions see: http://www.ferc.gov/industries/electric/indus-act/trans-invest.asp.

${ }^{15}$ Some of these investments have meanwhile been commissioned such as the $\$ 2.5$ billion Tehachapi renewable transmission project by Southern California Edison that was included in the scheme in 2007 and was commissioned in December 2016, whereas other investments have been delayed such as the \$1.6 billion RITEline project that was accepted in the scheme on the strict (suspending) condition that it had to be included in the regional transmission plan of PJM, which had not yet happened by the end of 2016 .
} 
2016; EEI, 2016); twenty-five projects by Southern California Edison, worth more than $\$ 4.5$ billion (EEI, 2015; Southern California Edison, 2016); and the more than $\$ 1$ billion Grand Rivers project by Ameren in the Missouri-Illinois area (EEI, 2015).

This available evidence is in line with the findings of Brunekreeft and Borrmann (2011), who argue that regulatory frameworks that combine elements of cost-of-service and incentive-based regulation are able to accelerate investment, citing the premium return on transmission investment provided by regulators in Italy and the United States.

Figure 3: historic transmission investment in Italy 2004-2013 (million euro, nominal) (source: AEEGSI, 2015qqq 464-15)

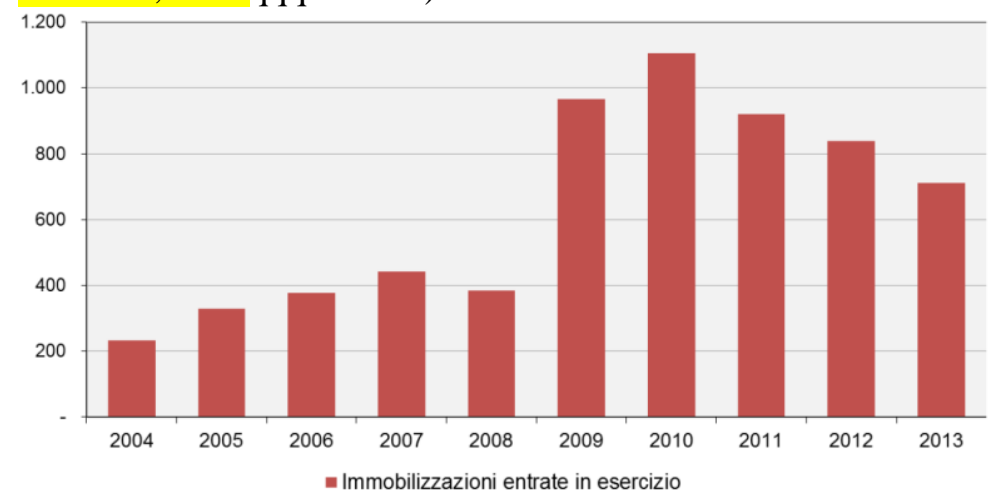

Figure 4: Historic transmission investment in the U.S. 1984-2015 (million U.S. dollar, nominal) (data from EEI, 2014, 2016).

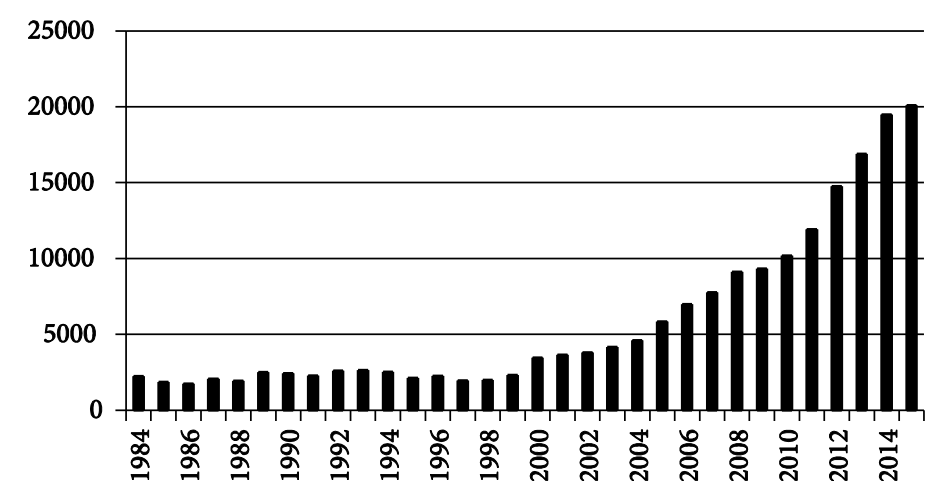

\section{Learning costs involved in dedicated incentives}

In this section, we illustrate the significant learning costs involved in implementing dedicated incentives. We first discuss how the Italian regulatory practice evolved across regulatory periods to arrive its current design, and then how the U.S. regulatory practice evolved based on a series of key cases.

\subsection{Evolution of the Italian regulatory practice across regulatory periods}

Italy started with dedicated regulatory incentives for strategic transmission investments in 2004 during the second period of the regulatory framework. The initial setup did not include a case-by-case element, but this was introduced in the third regulatory period and fine-tuned in the fourth regulatory period.

Second regulatory period: no case-by-case assessments 
Initially, during the second regulatory period, the dedicated regulatory incentive scheme in Italy operated without case-by-case project assessments. Important transmission investment was remunerated two percentage points more than regular investment and this increased return on investment was granted for twelve years upon the project being approved by the Ministry of Industry (AEEG, 2004a, 2004b, 2004c, 2007b). This approval formed the only level of assessment, but it is unclear on what basis the ministry granted approval.

\section{Third regulatory period: start of case-by-case assessments}

Important changes were introduced to the framework before the start of the third regulatory period 2008-2011 (AEEG, 2007a, 2007b). Regarding the access to the investment incentives, there were two important changes. First, the regulatory authority for energy, AEEG, was put in charge of controlling the access of projects to the scheme. Second, project categories were introduced to determine the eligibility of a project for dedicated incentives.

Regarding the types of incentives that can be granted under the scheme, there were two important changes. First, the return on investment premium was increased to three percentage points. Second, the regulatory authority introduced an acceleration incentive for work in progress (AEEG, 2007b). This acceleration incentive granted a three percent premium for construction work in progress in combination with a requirement to meet the planned commissioning date (AEEG, 2008). In case of a delay, the project developer had to return the premium received for work in progress, whereas in the case of early commissioning the premium return on investment was extended beyond twelve years by the number of months that the project was early.

By the end of the third regulatory period, the regulatory authority observed that the implementation pace of important projects was still slow (AEEG, 2010a). The existing acceleration mechanism was clarified by separating the incentive for work in progress from the incentive for timely commissioning. This also led to the introduction of new tools to administer the incentives. Milestones with a $70 \%$ threshold were introduced to administer the work in progress incentive. These incentives, as discussed above and still implemented today, were tested for the first time in 2010 and 2011 on 22 important transmission projects admitted into the scheme (AEEG, 2010b, 2011a, 2012).

\section{Fourth regulatory period: the fine-tuning of case-by-case assessments}

Most of the changes introduced during the third regulatory period were confirmed for further use during the fourth regulatory period, 2012-2015. The premium return on investment for completed projects continues to be granted automatically without case-by-case assessment, but the level of the premium was reduced again to two percentage points on top of the standard remuneration (AEEG, $2011 b, 2011 c)$. The new work-in-progress incentives and new incentives for delayed projects were also continued, but remained voluntary.

The number of projects admitted into the scheme during the fourth regulatory period that opted in on all incentives rose to twenty-five projects, with some of the projects being carried over from the previous period (AEEG, 2013a; AEEGSI, 2014b).

\section{Fifth regulatory period: transition towards output based incentives}

The new rules for the fifth regulatory period, 2016-2023 (AEEGSI, 2015a, 2015b), confirmed the existing commitments to projects that started in the previous regulatory periods. For new projects, however, new rules move towards output based incentives. In a transitory period, a premium return on investment of one percentage point for twelve years can still be granted to projects under two cumulative conditions. The first condition requires that significant project expenditure upwards of twenty-five percent of the expected costs had to have occurred by the end of 2015, meaning that the project was well underway during the fourth regulatory period. The second requirement to be eligible for the transitory scheme is that the project must be included in the annual transmission development plan of 2017 at the latest and it must be commissioned by 2019 .

\subsection{Evolution of the U.S. regulatory practice based on key cases}


The U.S. started implementing dedicated regulatory incentives for strategic transmission investments in 2006 through FERC Orders 679 and 679-A (FERC, 2006b, 2006c). Here we discuss some of the key cases that have gradually clarified the case-by-case assessment of strategic importance, project risk, and appropriateness of dedicated incentives.

\section{Key cases for the assessment of project importance}

In a case involving Duquesne Light Company (FERC, 2007b), FERC made a distinction between eight projects included in a Regional Transmission Expansion Plan (RTEP) for which the reliability impact had been evaluated and fourteen projects that were mentioned in a RTEP without such an evaluation. The eight projects were presumed to be important based on their inclusion in the RTEP, whereas the latter fourteen were only admitted conditionally pending the company's submission of sufficient evidence of their importance.

In a ruling involving Baltimore Gas \& Electric Company (FERC, 2007c) FERC accepted the developer's private technical studies on the reliability impact as evidence of project importance. FERC has referred back to this key ruling to illustrate the type of evidence that can be used to demonstrate the importance of a transmission project.

In the rulings involving Tallgrass Transmission \& Prairie Wind Transmission (FERC, 2008d) and Ameren (FERC, 2011), FERC reconfirmed that inclusion in a RTEP is not a prerequisite for entry into the dedicated incentive scheme and granted provisional entry into the scheme pending full approval in a later stage. The regulator further clarified that granting entry, conditional or full, did not imply automatic inclusion in an ongoing RTEP process, which is the sole prerogative of the regional transmission operator.

\section{Key cases for the assessment of extraordinary project risk}

In the ruling involving Duquesne Light Company (FERC, 2007b), FERC accepted factual evidence showing that the project was challenging for the developer in terms of financing, permitting and technology. The regulator found that the evidence sufficiently demonstrated the extraordinary risk of the project.

In a case involving Baltimore Gas \& Electric Company (FERC, 2007c), FERC established a practice to assess the risk of a project by proxy, inquiring whether a project was "routine" or "non-routine". The ruling provided further guidance about what arguments FERC would consider for qualifying a project as non-routine, such as the size of the project, the impact of the project on the regional market, and the challenges faced by the project. Even though this assessment by proxy considers project risk, it does not evaluate whether the risk is extraordinary and thus warrants dedicated investment incentives.

In cases involving Westar (FERC, 2008b) and Pepco (FERC, 2008c), FERC had to decide whether or not to evaluate several submitted projects as a single project. The regulator declined to view the three projects in Westar as a single project, and subsequently found that two projects were unable to demonstrate extraordinary risk. The eight projects submitted in the Pepco filing, however, were accepted as a single project, meaning that the developer could demonstrate the riskiness at the aggregated level. In a cases involving the PJM Interconnection (FERC, 2009), FERC further explored the issue of grouped projects, stating that multiple projects can be submitted as a single project if there is supporting evidence of the interactions among the individual projects, adding another level of caseby-case assessment. The regulator also stated that multiple projects may be submitted as individual projects in a single application filing. In that case, the project developer must demonstrate the importance and risk of each project separately.

In 2012, FERC abandoned the assessment by proxy established in Baltimore Gas \& Electric Company (FERC, 2012). The newly introduced regulatory approach relies on a full case-by-case assessment of whether a project faces extraordinary risks that warrant dedicated incentives. 


\section{Key cases for the connection between risk and incentives}

In the ruling on Duquesne Light Company (FERC, 2007b), FERC granted a return premium that was lower than requested, indicating that the project's risk was already partly mitigated with other granted incentives. In that same ruling, the regulator clarified what factual evidence it would consider when deciding to grant the full cost recovery of construction work in progress by inclusion of these costs in the RAB.

In the ruling on Baltimore Gas \& Electric Company (FERC, 2007c), FERC granted the requested return premium for only two out of eight projects that entered the scheme, rejecting the premium for the other six projects based on their different risk profile. Furthermore, the regulator rejected the request for $100 \%$ cost recovery of construction work in progress on the grounds that there was insufficient evidence that the incentive was necessary to implement the project.

In Tallgrass Transmission \& Prairie Wind Transmission (FERC, 2008d), the granted return premium was lower than the level requested by the project developer because the allegedly innovative technology had been recognized as mature technology in other rulings by the regulator.

FEERC decided to expand the scope of the case-by-case assessments in its 2012 policy statement (FERC, 2012), requiring project developers to demonstrate what they have done to manage project risk, including their requests for risk-mitigating incentives, before applying for a premium return on investment. In the cases submitted after the 2012 policy statement, few requests were made for a premium return on investment, whereas this was standard practice before the policy statement.

\section{Conclusions and policy implications}

Although still controversial, more and more countries, including Germany, France, Great Britain, and the Netherlands, are applying or considering case-by-case dedicated incentives for strategic investment in electricity transmission infrastructure. Italy (since 2004) and the United States (since 2006) have the longest experience as detailed and compared in this paper. While the experiences in Italy and the United States do not provide definitive evidence that dedicated incentives schemes are appropriate for strategic investments, the available evidence of the respective schemes illustrates that both served the purpose for which they were implemented: accelerating strategically important investment in the transmission grid. To gain a deeper understanding of the dynamics between the regulatory parameters and new investments, empirical analysis is recommended.

Notwithstanding the apparently positive experiences in Italy and the United States, there also has been significant learning to reduce administrative costs and improve cost efficiency. Over time, both schemes have evolved towards more sophisticated models. In the United States, the federal regulator has clarified its scheme in a series of key decisions. In Italy, the regulatory authority started with a relatively simpler scheme of granting the same dedicated incentives to all investment classified as strategically important. Over the course of three regulatory periods, Italy's scheme was fine-tuned to increase the cost efficiency of the scheme. For instance, the premium return on investment was made conditional on the sufficient progress of the project, which was monitored via predefined milestones.

More sophistication, of course, also implies more complexity for the project developers that must apply for the dedicated incentives and the regulatory authorities that must administer the process. In the United States, the burden of proof is on the project developers who must demonstrate that their request for dedicated incentives is justified by extraordinary project risk. In Italy, the complexity is limited to the establishment and monitoring of project milestones for work-in-progress incentives, and to administer the possible penalty for delayed commissioning of the project.

The apparent success in Italy and the United States do not necessarily mean that all countries should follow their examples and provide dedicated incentives for strategically important investments within their regulatory frameworks on a case-by-case basis. Some countries might argue that the 
administrative costs are too high, particularly relative to benefits. For countries that implement a dedicated incentive scheme, it is important to consider the learning costs involved for all concerned parties, including regulatory authorities, project developers and investors. The final objective of the regulatory scheme remains to achieve a high quality service to final customers at the lowest cost possible regardless of how investment is incentivized.

\section{Acknowledgements}

The authors are grateful to Marco La Cognata and Paolo Terzilli who have been so kind to check our understanding of the Italian regulation for transmission investment.

\section{References}

ACER, 2014. Recommendation of the Agency for the Cooperation of Energy Regulators No 03/2014 of 27 June 2014 on incentives for projects of common interest and on a common methodology for risk evaluation.

AEEG, 2003. Tariffe per il servizio di trasporto e corrispettivi per i servizi di misura e vendita dell'energia elettrica per il periodo di regolazione 1 gennaio 2004- 31 dicembre 2007. 1 luglio 2003. http://www.autorita.energia.it, last accessed March 2015.

AEEG, 2004a. Tariffe per il servizio di trasporto e corrispettivi per i servizi di misura e vendita dell'energia elettrica per il periodo di regolazione 1 gennaio 2004- 31 dicembre 2007. 13 gennaio 2004. http://www.autorita.energia.it, last accessed March 2015.

AEEG, 2004b. Deliberazione 30 gennaio 2004, Testo integrato delle disposizioni dell'Autorità per l'energia elettrica e il gas per l'erogazione dei servizi di trasmissione, distribuzione, misura e vendita dell'energia elettrica per il periodo di regolazione 2004-2007 e disposizioni in materia di contributi di allacciamento e diritti fissi (deliberazione n. 5/04). http://www.autorita.energia.it, last accessed March 2015.

AEEG, 2004c. Relazione tecnica. Testo integrato delle disposizioni dell'Autorità per l'energia elettrica e il gas per l'erogazione dei servizi di trasmissione, distribuzione, misura e vendita dell'energia elettrica per il periodo di regolazione 2004-2007 e disposizioni in materia di contributi di allacciamento e diritti fissi (deliberazione n. 5/04). 30 gennaio 2004. http://www.autorita.energia.it, last accessed March 2015

AEEG, 2005. Annual report to the European Commission on the state of the services and on the regulation of the electricity and gas sectors. 31 July 2005. http://www.autorita.energia.it, last accessed March 2015.

AEEG, 2007a. Deliberazione 29 dicembre 2007, n. 348/07 Testo integrato delle disposizioni dell'Autorità per l'energia elettrica e il gas per l'erogazione dei servizi di trasmissione, distribuzione e misura dell'energia elettrica per il periodo di regolazione $2008-2011$ e disposizioni in materia di condizioni economiche per l'erogazione del servizio di connessione. Allegato A. http://www.autorita.energia.it, last accessed March 2015.

AEEG 2007b. Allegato A. Testo integrato delle disposizioni dell'Autorità per l'energia elettrica e il gas per l'erogazione dei servizi di trasmissione, distribuzione e misura dell'energia elettrica. Periodo di regolazione 2008-2011. http://www.autorita.energia.it, last accessed March 2015.

AEEG, 2008. Deliberazione 19 dicembre 2008 - ARG/elt 188/08 Aggiornamento per l'anno 2009 delle tariffe per l'erogazione dei servizi di trasmissione, distribuzione e misura dell'energia elettrica e delle condizioni economiche per l'erogazione del servizio di connessione. http://www.autorita.energia.it, last accessed March 2015.

AEEG, 2010a. Deliberazione 11 giugno 2010 - ARG/elt 87/10 Disposizioni in materia di accelerazione degli investimenti di sviluppo della rete di trasmissione nazionale di cui all'articolo 3, della deliberazione dell'Autorità per l'energia elettrica e il gas 19 dicembre 2008 , ARG/elt 188/08. http://www.autorita.energia.it, last accessed March 2015.

AEEG, 2010b. Delibera ARG/elt 130/10 Approvazione della proposta di interventi di sviluppo della RTN ai sensi del comma 11.2 della deliberazione dell'Autorità per l'energia elettrica e il gas 11 giugno 2008, ARG/elt 87/10. http://www.autorita.energia.it, last accessed March 2015.

AEEG. 2011a. Delibera ARG/elt 101/11 Accertamento dell'incentivazione all'accelerazione degli investimenti di sviluppo della rete di trasmissione nazionale, di cui all'articolo 8 della deliberazione dell'Autorità per l'energia elettrica e il gas 11 giugno 2008, ARG/elt 87/10. Allegato A alla deliberazione ARG/elt xx/11 - Raggiungimento Milestone anno 2010. 21 luglio 2011. http://www.autorita.energia.it, last accessed March 2015.

AEEG, 2011b. Deliberazione 29 dicembre 2011 - ARG/elt 199/11 Disposizioni dell'Autorità per l'energia elettrica e il gas per l'erogazione dei servizi di trasmissione, distribuzione e misura dell'energia elettrica per il periodo di regolazione 2012-2015 e disposizioni in materia di condizioni economiche per l'erogazione del servizio di connessione. http://www.autorita.energia.it, last accessed March 2015.

AEEG, 2011c. Allegato A. Testo integrato delle disposizioni dell'Autorità per l'energia elettrica e il gas per l'erogazione dei servizi di trasmissione e distribuzione dell'energia elettrica. http://www.autorita.energia.it, last accessed March 2015.

AEEG. 2012. Deliberazione 31 maggio 2012 228/2012/R/EEL Accertamento dell'incentivazione all'accelerazione degli investimenti di sviluppo della rete di trasmissione nazionale. http://www.autorita.energia.it, last accessed March 2015.

AEEG, 2013a. Deliberazione 31 gennaio 2013 40/2013/R/EEL individuazione degli investimenti strategici di sviluppo della rete di trasmissione nazionale e delle relative date obiettivo e milestone. http://www.autorita.energia.it, last accessed March 2015

AEEG, 2013b. Deliberazione 24 ottobre 2013 469/2013/R/EEL Accertamento dello stato di raggiungimento delle milestone degli investimenti strategici di sviluppo della rete di trasmissione nazionale relativi al primo semestre dell'anno 2013. http://www.autorita.energia.it, last accessed March 2015. 
AEEGSI, 2014a. Deliberazione 6 giugno 2014 259/2014/R/EEL Accertamento dello stato di raggiungimento delle milestone degli investimenti strategici di sviluppo della rete di trasmissione nazionale, relativi al secondo semestre dell'anno 2013. http://www.autorita.energia.it, last accessed March 2015.

AEEGSI, 2014b. Deliberazione 23 dicembre 2014 654/2014/R/EEL Aggiornamento delle milestone e delle date obiettivo degli investimenti strategici di sviluppo della rete di trasmissione nazionale. http://www.autorita.energia.it, last accessed March 2015.

AEEGSI, 2015qqq, Documento per la consultazione 464/2015/R/EEL Servizio di trasmissione dell'energia elettrica: un modello di sviluppo selettivo degli investimenti. 1 ottobre 2015. http://www.autorita.energia.it, last accessed April 2017.

AEEGSI, 2015a. Deliberazione 23 dicembre 2015 654/2015/R/EEL Regolazione tariffaria dei servizi di trasmissione, distribuzione e misura dell'energia elettrica, per il periodo di regolazione 2016-2023. http://www.autorita.energia.it, last accessed May 2016

AEEGSI, 2015b. Allegatto A. Testo integrato delle disposizioni per l'erogazione dei servizi di trasmissione e distribuzione dell'energia elettrica. http://www.autorita.energia.it, last accessed May 2016

AEEGSI 2016a. Deliberazione 24 giugno 2016 335/2016/R/EEL Accertamento dello stato di raggiungimento delle milestone degli investimenti strategici di sviluppo della rete di trasmissione nazionale, relativi all' anno 2015. http://www.autorita.energia.it, last accessed April 2017

AEEGSI 2016b. Allegato A alla deliberazione 335/2016/R/eel - Accertamento raggiungimento milestone 2015. http://www.autorita.energia.it, last accessed April 2017.

Benjamin, R., 2007. Principles for Interregional Transmission Expansion. The Electricity Journal, Volume 20, Issue 8, October 2007, Pages $36-47$.

Brunekreeft, G.; Meyer, R., 2011. Regulation and Regulatory Risk in the Face of Large Transmission Investment. Competition and Regulation in Network Industries 12(2), 155-172.

Brunekreeft, G., Borrmann, J., 2011. The effect of monopoly regulation on the timing of investment. Bremen Energy Working Paper Series No 9, May 2011.

Daileader Jr., R.L., 2007. Real World Issues in Encouraging Transmission Investment in the Wake of Order 679. Natural Gas \& Electricity: Special Issue: Focus: Environment and Clean Fuels Debate Now Everywhere and All the Time, Volume 23, Issue 9, pages 1-31, April 2007.

Dominion, 2016. Dominion transmission projects. https://www.dom.com/corporate/what-we-do/electricity/transmission-lines-and-projects, last accessed May 2016.

EC, 2013a. Regulation (EU) No 347/2013 of the European Parliament and of the Council of 17 April 2013 on guidelines for trans-European energy infrastructure and repealing Decision No 1364/2006/EC and amending Regulations (EC) No 713/2009, (EC) No 714/2009 and (EC) No $715 / 2009$.

EC, 2013b. Commission delegated Regulation (EU) No 1391/2013 of 14.10.2013 amending Regulation (EU) No $347 / 2013$ of the European Parliament and of the Council on guidelines for trans-European energy infrastructure as regards the Union list of projects of common interest.

EEI, 2013. Transmission Investment: Adequate Returns and Regulatory Certainty Are Key. June 2013.

EEI, 2014. Construction Expenditure Data, In: EEI, 2014. Statistical Yearbook/2013.

EEI, 2015. Transmission Projects: At A Glance. March 2015.

EEI, 2016. Transmission Projects: At A Glance. December 2016.

FERC, 2006a. FY 2007 Congressional Performance Budget Request. February 2006.

FERC, 2006b. Promoting Transmission Investment Through Pricing Reform. 116 FERC. Order 679. Docket No. RM06-4-000, 20 July 2006.

FERC, 2006c. Promoting Transmission Investment Through Pricing Reform. 18 CFR Part 35. Order 679-A. Docket No. RM06-4-001, 22 December 2006

FERC, 2007a. FY 2008 Congressional Performance Budget Request. February 2007.

FERC, 2007b. 118 FERC II 61,087. Duquesne Light Company. Order conditionally granting declaratory order, accepting proposed formula rates, subject to conditions and establishing hearing and settlement judge procedures. Docket Nos. EL06-109-000, ER06-1549-000 and ER06-1549-001. February 6, 2007.

FERC, 2007c. 120 FERC II 61,084. Baltimore Gas and Electric Company. Order accepting revised tariff sheets subject to revision and establishing technical conference. Docket Nos. ER07-576-000 and ER07-576-001. July 24, 2007.

FERC, 2008a. FY 2009 Congressional Performance Budget Request. February 2008

FERC, 2008b. 122 FERC II 61,268. Westar Energy, Inc. Order denying, in part, and granting, in part, petition for declaratory order, and accepting, in part, and denying, in part, proposed formula rates, subject to conditions and establishing hearing and settlement judge procedures. Docket Nos. EL08-31-000 and ER08-396-000. March 24, 2008.

FERC, 2008c. 124 FERC II 61,176. Pepco Holdings, Inc. Order granting transmission rate incentive. Docket Nos. ER08-686-000 and ER08686-001. August 22, 2008.

FERC, 2008d. 125 FERC II 61,248. Tallgrass Transmission LLC \& Prairie Wind Transmission, LLC. Order consolidating proceedings, granting rate incentives, conditionally accepting tariff revisions and establishing hearing and settlement procedures. Docket No. ER09-35000 and ER09-36-000. December 2, 2008.

FERC, 2009. 126 FERC II 61,281. Pioneer Transmission, LLC. Order on transmission rate incentives and formula rate proposal. Docket Nos. ER09-75-000 and ER09-75-001. March 27, 2009. 
FERC, 2011. 135 FERC II 61,142. Ameren Services Company. Order on transmission rate incentives. Docket No. EL10-80-000. May 19, 2011.

FERC, 2012. Promoting Transmission Investment Through Pricing Reform. 141 FERC. Docket No. RM11-26-000, 15 November 2012.

Glachant, J.M., Saguan, M., Rious, V., Douguet, S., 2013. Incentives for investments: Comparing EU electricity TSO regulatory regimes. FSR Research Report. December 2013. DOI:10.2870/80768.

Helm, D., 2009. Utility regulation, the RAB and the cost of capital. Paper for Competition Commission Spring Lecture 2009. http://www.dieterhelm.co.uk/node/676, last accessed 21 February 2016.

Hirst, E., Kirby, B, 2001. Transmission Planning for a Restructuring United States Electricity Industry, Edison Electricity Institute, Washington, DC, June 2001.

Hirst, E., 2004. United States Transmission Capacity: Present Status and Future Prospects, Washington, DC, Edison Electric Institute, Aug. 2004.

Jamasb, T., Pollitt, M., 2001. Benchmarking and regulation: international electricity experience. Utilities Policy, 9(3): 107-130.

Lévêque, F., Glachant, J.M., Saguan, M. de Muizon, G., 2009. How to rationalize the debate about 'EU energy third package'? Revisiting criteria to compare electricity transmission organizations. EUI working paper RSCAS 2009/15. http://hdl.handle.net/1814/11028, last accessed, March 2015.

Lum, R., 2012. FERC Order 679 responsible for \$23bn of transmission infrastructure investment in 2012-2016 period. 13 July 2012. http://www.transmissionhub.com/articles/2012/07/ferc-order-679-responsible-for-23bn-of-transmission-infrastructure-investment-in-20122016-period.html, last accessed May 2016.

Meeus, L., 2014. Offshore grids for renewables: do we need a particular regulatory framework? Economics of Energy \& Environmental Policy, Volume 4, Number 1. http://dx.doi.org/10.5547/2160-5890.4.1.lmee

Meeus, L., Keyaerts, N., 2014. The Role of the EU and ACER to Ensure an Adequate Regulatory Framework for Projects of Common Interest. FSR Policy Brief, Issue 2014/05. September 2014. http://hdl.handle.net/1814/32851, last accessed March 2015.

Microeconomix, 2008. La régulation incitative appliquée au transport de l'électricité. http://www.microeconomix.fr/publications/laregulation-incitative-appliquee-au-transport-de-lelectricite, last accessed September 2014.

Pacificorp, 2016. Energy Gateway. http://www.pacificorp.com/energygateway, last accessed May 2016.

Snarr, S.W., 2010. FERC Rate Incentives for Transmission Infrastructure Development. The Electricity Journal, Volume 23, Issue 2, March 2010, Pages 6-17.

Southern California Edison, 2016. Reliability investments. https://www.sce.com/wps/portal/home/about-us/reliability, last accessed May 2016.

Terna, 2006. Piano strategico 2006-2010. http://www.terna.it, last accessed April 2017.

Terna, 2010. Piano strategico 2010-2014. http://www.terna.it, last accessed April 2017.

Terna, 2014. Piano strategico 2014-2018. http://www.terna.it, last accessed April 2017.

Terna, 2012. Rapporto di sostenibilita. http://ternacsr2012.message-asp.com/it/responsabilita-servizio-elettrico/sviluppo-rete, last accessed May 2016.

U.S.-Canada Power System Outage Task Force, 2004. Final Report on the August 14, 2003 Blackout in the United States and Canada: Causes and Recommendations. April 2004. http://energy.gov/sites/prod/files/oeprod/DocumentsandMedia/BlackoutFinal-Web.pdf, last accessed March 2015. 